O. Sukharevsky, V. Vasilets, I. Ryapolov

\author{
Ivan Kozhedub Kharkiv National Air Force University, Kharkiv
}

\title{
SCATTERING CHARACTERISTICS OF SURFACE SHIPS WITH COMPLEX SHAPE
}

Based on the previously developed by the authors method for estimating the scattering characteristics of objects located near the interface between two half-spaces, the scattering data of a large Project 775 landing ship (NATO codification: Ropucha) are obtained. A surface model of the ship under study and the results of calculations of its scattering characteristics are given. Scattering characteristics were obtained for different probing conditions. The radar cross-section circular diagrams, mean and median radar cross-section values, averaged in different azimuth aspect ranges of probing for the object under study are presented.

Keywords: radar cross-section, surface ship, scattering characteristics, circular diagram.

\section{Introduction}

Obtaining radar information about real objects through field and physical experiments is associated with significant financial, organizational and time costs. Therefore, the method of mathematical modeling can be considered as the most accessible way to obtain information about object scattering characteristics. Classical asymptotic methods of high-frequency diffraction do not allow, without proper generalizations and improvements, to calculate the scattering characteristics taking into account such factors as the complexity of the object surface, the presence of various radar absorbing materials on the object surface, including on the surface edges, the presence of the underlying surface, the possibility of bistatic reception. In this connection, obtaining the scattering characteristics of real surface objects requires the development of the electromagnetic scattering theory and the creation of generalized methods for calculating radar characteristics for complex shaped objects with an non-perfectly reflecting surface.

The proposed method is based on separate estimation of the contributions of the smooth and edge parts of the object surface to the total scattered field. The total field on the smooth parts of the object surface is calculated using the Kirchhoff method or its generalization to the case of radar absorbing coatings.

The field scattered by the edge parts of the surface is calculated using the solution of a model problem on diffraction of an obliquely incident plane monochromatic wave on a perfectly conducting wedge with a radar absorbing cylinder on the edge. The proposed method allows calculating the radar cross-section (RCS) of a perfectly conducting object in free space, completely or partially covered with a radio absorbing material (RAM).

Also, the object can have surface irregularities in the form of fractures, also provided with radio absorbing coatings (RAC). RCS can be obtained for both monostatic and bistatic reception.

It should also be noted that the proposed method makes it possible to calculate the RCS of an object completely made of dielectric or composite materials.

For surface objects (Fig. 1) we propose a calculation method that allows taking into account the presence of the underlying surface with specified electromagnetic characteristics [1-5; 9-14].

Due to the presence of the "air-sea" interface, two mutually intersecting illuminated regions appear on the surface of the object, the first of which is caused by a direct wave incident from the probing point, and the second by a wave reflected from the sea surface.

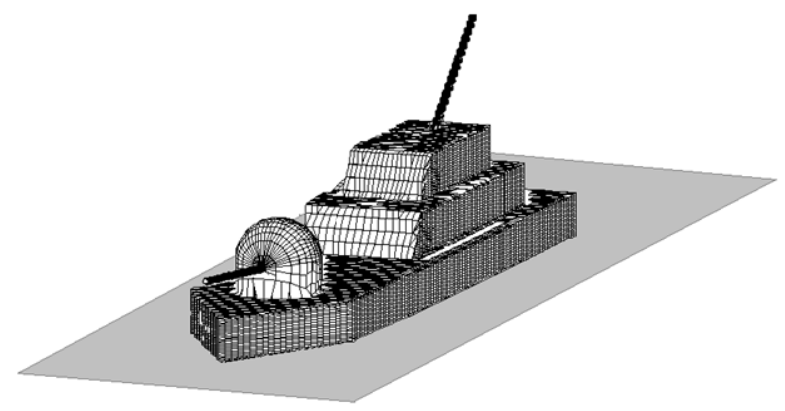

Fig 1. The model of surface object Source: developed by the authors.

The obtained integral representations allow indicating four main paths of electromagnetic wave propagation in the described system: "transmitter-objectreceiver", "transmitter-object-sea-receiver", "transmitter-sea-object-receiver", "transmitter-sea-object-seareceiver" (Fig. 2). For surface objects the method also allows to calculate scattering characteristics in the presence of RAC on the object surface.

In this paper, we consider and estimate scattering characteristics only for perfectly conducting surface objects, such as the Large Landing Ship (LLS) series 775 (Ropucha-class landing ship).

Scattering characteristics calculation for a complex shaped object requires a mathematical description of its 
surface [10]. In addition, it is necessary to have information on the electromagnetic characteristics of the materials of which the object is made.

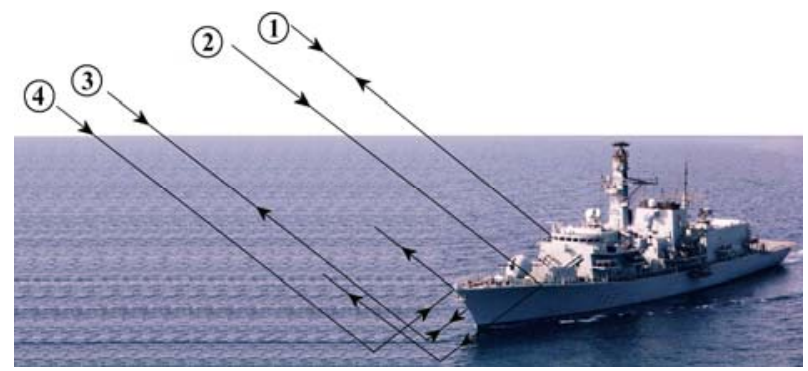

Fig 2. Four main paths of electromagnetic wave propagation in surface object probing Source: [10].

In the process of developing and improving methods for calculating scattering characteristics, as well as with the development of computational tools, various methods were used to model the object surface. However, even now, describing the surface of a complex shaped object requires a large volume of manual work.

Description of the object's surface and of its individual parts was done using the method presented in [1]. The method involves approximation of smooth parts by segments of three-axial ellipsoids, and the edges were represented by wedges with straight or elliptical edges, the wedges' angles corresponding to the geometry of the object.

Using the method described above, we designed the object's surface model. This model is suitable for electrodynamic computations.

The method proposed in $[1 ; 4]$ and describing the electromagnetic wave scattering by an object located near the boundary of a homogeneous half-space (possibly with complex parameters) can be used (as mentioned above) to estimate the scattering characteristics of surface ships.

The method accounts re-reflections between smooth parts of the reflector surface. Smooth parts of objects surface is split into triangle facets. For each $i$-th facet of some smooth surface part the normal vector $\vec{n}$ and mirror reflection direction $\vec{R}^{1}$ for corresponding to direction $\vec{R}^{0}$ of incident wave are found. The rays with mirror reflection direction $\vec{R}^{1}$ are built from each facet vertex to find intersections of rays and other smooth parts of object. If there are intersections for all three rays with single smooth part, the $j$-th facet is formed on this smooth part. The vertices of $j$-th facet are the intersection points of re-reflection rays with direction $\vec{R}^{1}$ and another smooth part of object surface. There is the additional re-reflection plane wave from direction $\vec{R}^{1}$ with complex vector $\vec{p}^{1}$ obtained with physical optics approximation for $i$-th triangle facet. The additional field, which falls to $j$-th facet, has additional phase incursion. This phase incursion can be obtained similar to phase incursion in marine object field consideration for electromagnetic field re-reflection from sea surface [10]. The field scattered by $j$-th facet in reception direction $\vec{r}^{0}$ (with accounting additional incident wave from direction $\vec{R}^{1}$ ) is calculated with physical optics approximation. The algorithm of following re-reflection can be repeated for accounting multiple re-reflections. The realization of proposed algorithm allows calculating multiple re-reflections and estimate scattering characteristics of such objects as trihedral corner reflector.

Described above methods need calculating reflection factor for sea surface (in mirror direction).

At the same time the surface can have inequalities and roughness induced by wind waves. For its accounting it is necessary to apply some averaged reflection factor. This factor can be obtained [14-16] with multiplication of $\exp \left(-2\left(k_{o} \sigma \cos \theta\right)^{2}\right)$, where $k_{o}$ is wavenumber in free space, $\sigma$ is roof-mean-square deviation of roughness height chance quantity, $\theta$ is reference angle for smooth averaged sea surface.

By adding together components scattered from smooth surface part and local edge scatterers of the object, one can estimate the field scattered from the object standing on the underlying surface [10].

\section{Statement of basic materials}

When computing scattering characteristics of marine object, we assumed the following elevation angles of its radar illumination (Fig. 3): $0,34^{\circ}-$ illumination from the far line of target detection (illumination frequency of $12,6 \mathrm{GHz}-2,38 \mathrm{~cm}$ wavelength); $0,1^{\circ}-$ illumination from the near line of target detection (illumination frequency of $36,6 \mathrm{GHz}-0,82 \mathrm{~cm}$ wavelength). Increment in azimuth aspect was set to $1^{\circ}$, the azimuth aspect angle $\beta$ itself being counted off counterclockwise from the bow-on direction $\left(0^{\circ}\right.$ corresponds to the bow-on illumination, $180^{\circ}$ corresponds to the stern-on illumination).

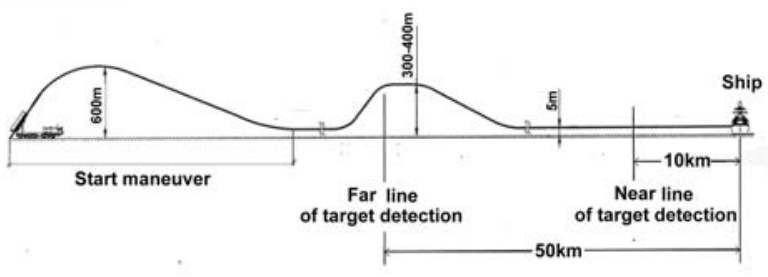

Fig 3. Geometry of the marine object detection Source: developed by the authors.

Computation results are given for the case of monostatic radar given two orthogonal polarizations of illumination signal: the horizontal one, for which the vector of electrical field intensity of illumination wave is parallel to the sea surface; and the vertical one, for which the vector of electrical field intensity of illumina- 
tion wave is orthogonal to horizontal one and belongs to the plane that is perpendicular to the sea surface plane and that includes at the same time the propagation direction vector of plane incident wave.

We present the computation results obtained in assumption of two types of sea surface. These two types are the following: smooth sea $\left(\varepsilon^{\prime}=80+j 3,4\right)$; rough sea with the same parameters but it have such roughness, that reflection factor for sea surface tends to zero. Relative permeability for the both surface was equal to unit. Using smooth sea surface we obtain high level of ship RCS in ideal conditions. Using rough sea with zero reflection factor we obtain more low level of ship RCS than for smooth sea surface. In this case we obtain maximum and minimum boundaries of ship RCS.

The Ropucha (toad), or Project 775 class landing ships are classified in the Russian Navy as "large landing craft" (Fig. 4). They were built in Poland in the Stocznia Północna shipyards, in Gdańsk. They are designed for beach landings and can carry a 450-ton cargo. The ships have both bow and stern doors for loading and unloading vehicles, and the $630 \mathrm{~m}^{2}$ of vehicle deck stretches the length of the hull. Up to 25 armored personnel carriers can be embarked [17].

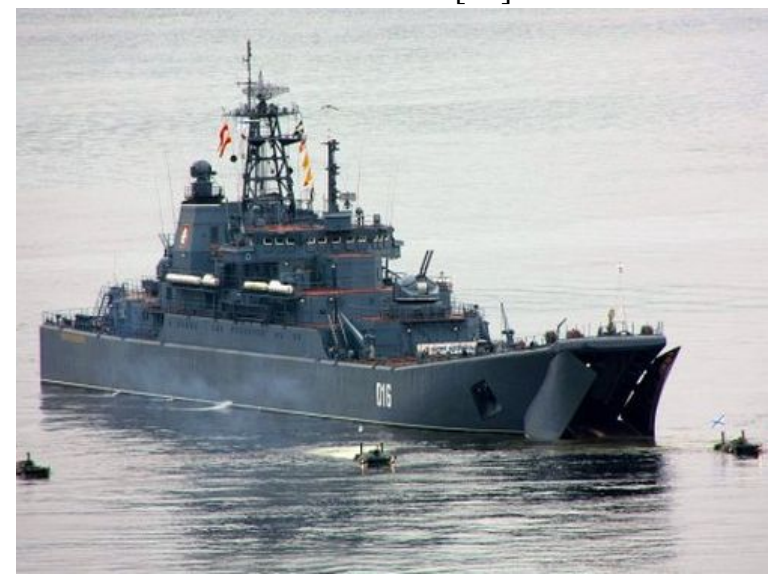

Fig. 4. Ropucha-class landing ship Source: [10].

Ship characteristics: displacement is 2,200 tons standard, 4,080 tons full load, length is $112,5 \mathrm{~m}$, beam is $15 \mathrm{~m}$, draft is $3,7 \mathrm{~m}$, speed is 18 knots $(33 \mathrm{~km} / \mathrm{h})$, range is $6,100 \mathrm{~km}$ at $15 \mathrm{knots}(28 \mathrm{~km} / \mathrm{h})$.

In our computations, we used the perfectly conducting computer model of the ship surface shown in Fig. 5. Model surface consists of 160 parts of triaxial ellipsoids and 140 plain edges.

Figures below show diagrams of mean and median RCS and circular diagrams of RCS obtained for Ropucha-class ship model. The results are given for vertical and horizontal polarization, two types of sea surface and two illumination frequencies.

\section{Ship scattering characteristics for frequency $12,6 \mathrm{GHz}$ and smooth sea.}

Horizontal polarization. In Fig. 6 the RCS circle diagram is shown. Circular mean RCS of ship model is equal $82839138 \mathrm{~m}^{2}$. Circular median RCS (RCS value used for calculation of object detection range with probability 0,5$)$ is equal $3542627 \mathrm{~m}^{2}$.

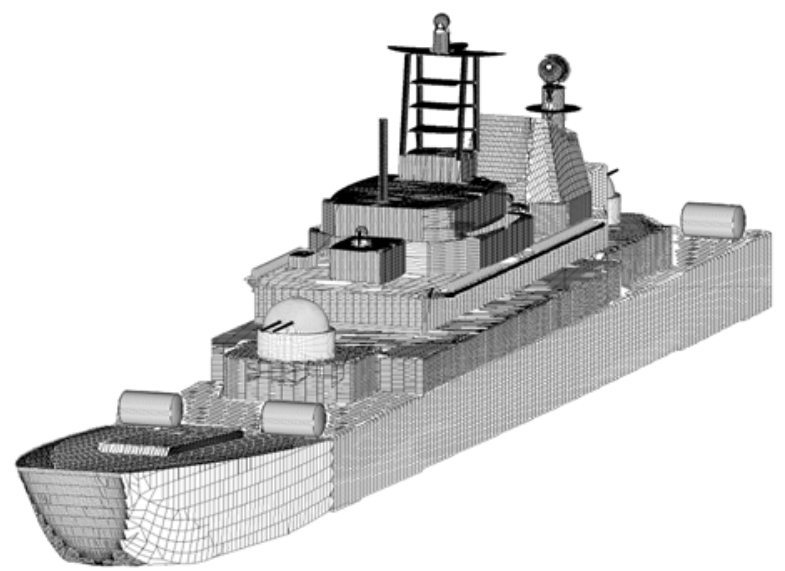

Fig. 5. Computer model of Ropucha-class ship surface Source: developed by the authors.

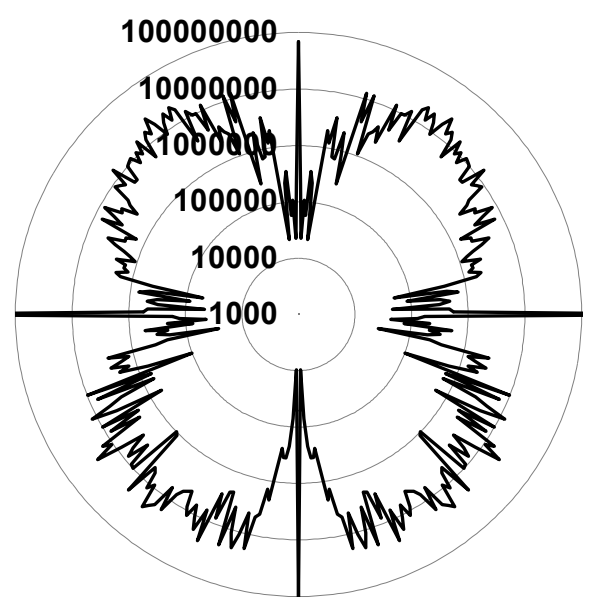

Fig. 6. The RCS circle diagram of ship model (frequency $12,6 \mathrm{GHz}$ and smooth sea, horizontal polarization) Source: developed by the authors.

In Fig.7 diagrams of mean and median RCS of the ship model in three sectors of azimuth aspect are shown. In Fig. 8 diagrams of mean and median RCS of the ship model in 15-degree sectors of azimuth aspect are shown.

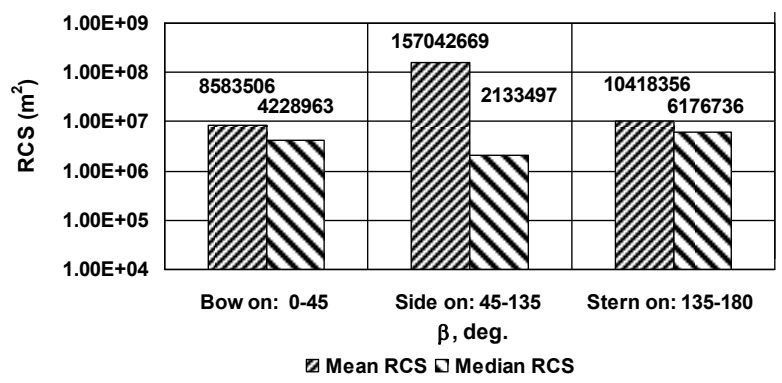

Fig. 7. Diagrams of mean and median RCS of the ship model in three sectors of azimuth aspect (frequency $12,6 \mathrm{GHz}$ and smooth sea, horizontal polarization)

Source: developed by the authors. 


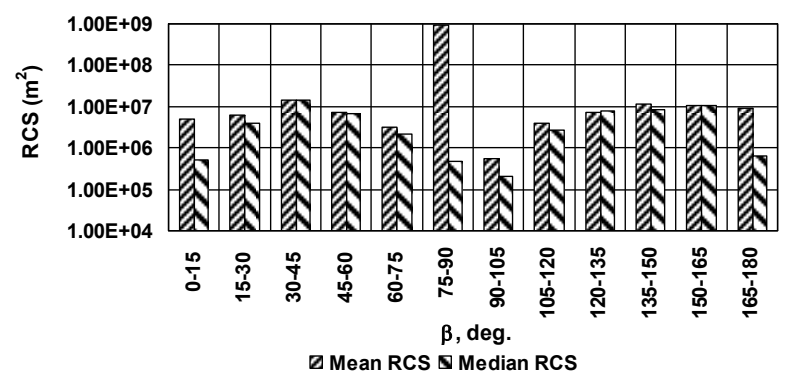

Fig. 8. Diagrams of mean and median RCS of the ship model in 15-degree sectors of azimuth aspect

(frequency 12,6 GHz and smooth sea, horizontal polarization)

Source: developed by the authors.

Vertical polarization. In Fig. 9 the RCS circle diagram is shown. Circular mean RCS of ship model is equal $68662028 \mathrm{~m}^{2}$. Circular median RCS (RCS value used for calculation of object detection range with probability 0,5 ) is equal $2454024 \mathrm{~m}^{2}$.

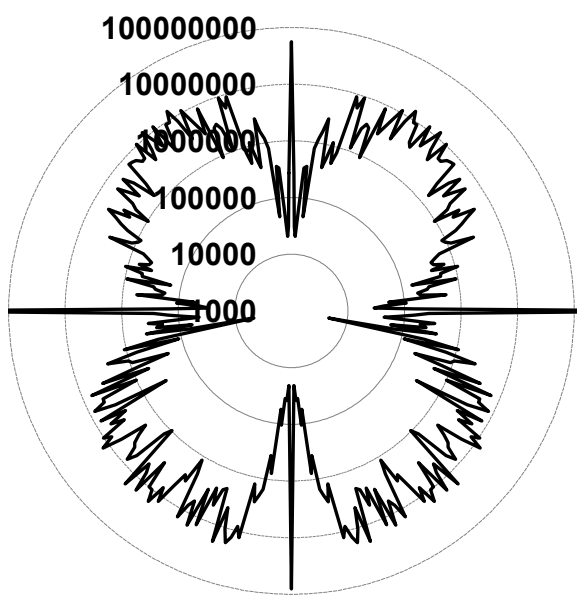

Fig. 9. The RCS circle diagram of ship model (frequency 12,6 GHz and smooth sea, vertical polarization)

Source: developed by the authors.

In Fig. 10 diagrams of mean and median RCS of the ship model in three sectors of azimuth aspect are shown. In Fig. 11 diagrams of mean and median RCS of the ship model in 15-degree sectors of azimuth aspect are shown

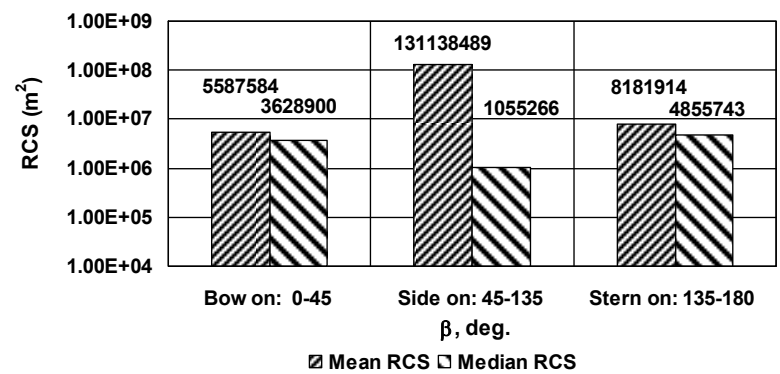

Fig. 10. Diagrams of mean and median RCS of the ship model in three sectors of azimuth aspect (frequency

$12,6 \mathrm{GHz}$ and smooth sea, vertical polarization) Source: developed by the authors.

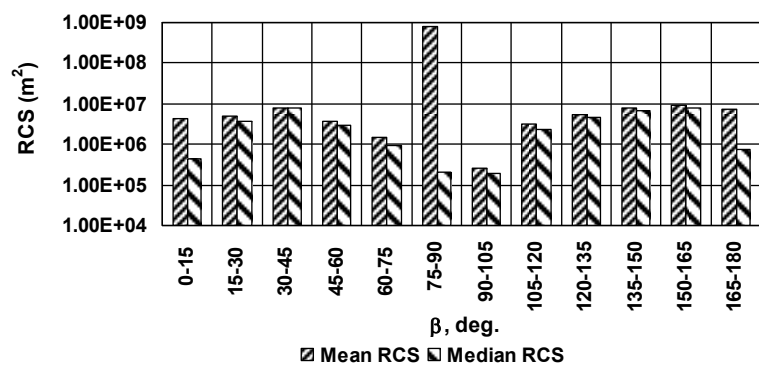

Fig. 11. Diagrams of mean and median RCS of the ship model in 15-degree sectors of azimuth aspect

(frequency 12,6 GHz and smooth sea, vertical polarization)

Source: developed by the authors.

Ship scattering characteristics for frequency $12,6 \mathrm{GHz}$ and rough sea

Horizontal polarization. In Fig. 12 the RCS circle diagram is shown. Circular mean RCS of ship model is equal $305381 \mathrm{~m}^{2}$. Circular median RCS (RCS value used for calculation of object detection range with probability 0,5$)$ is equal $20736 \mathrm{~m}^{2}$.

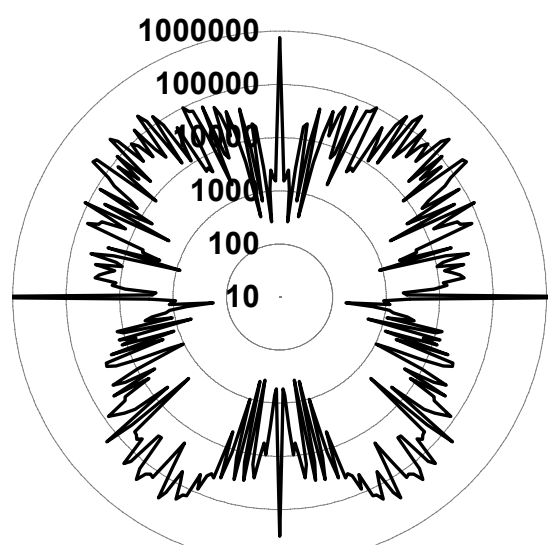

Fig. 12. The RCS circle diagram of ship model (frequency 12,6 GHz and rough sea, horizontal polarization)

Source: developed by the authors.

In Fig. 13 diagrams of mean and median RCS of the ship model in three sectors of azimuth aspect are shown. In Fig. 14 diagrams of mean and median RCS of the ship model in 15-degree sectors of azimuth aspect are shown.

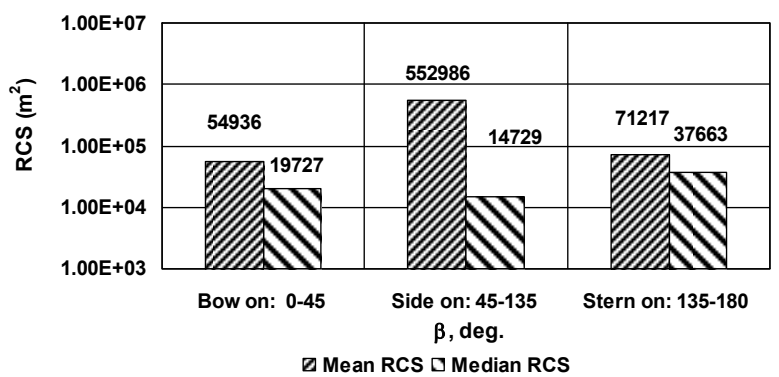

Fig. 13. Diagrams of mean and median RCS of the ship model in three sectors of azimuth aspect (frequency

$12,6 \mathrm{GHz}$ and rough sea, horizontal polarization) Source: developed by the authors. 


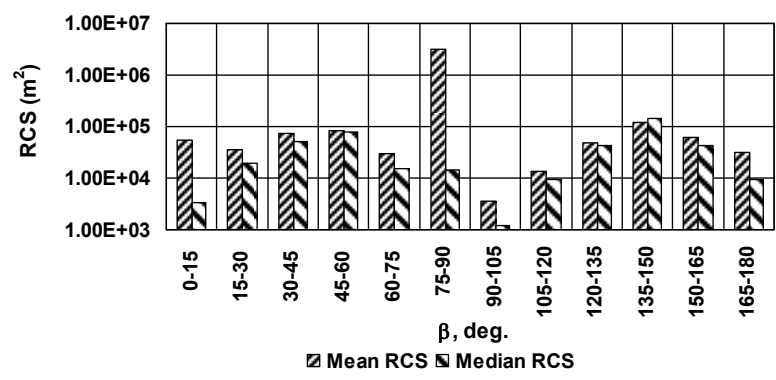

Fig. 14. Diagrams of mean and median RCS of the ship model in 15-degree sectors of azimuth aspect (frequency 12,6 GHz and rough sea, horizontal polarization)

Source: developed by the authors.

Vertical polarization. In Fig. 15 the RCS circle diagram is shown. Circular mean RCS of ship model is equal $310604 \mathrm{~m}^{2}$. Circular median RCS (RCS value used for calculation of object detection range with probability 0,5 ) is equal $24210 \mathrm{~m}^{2}$.

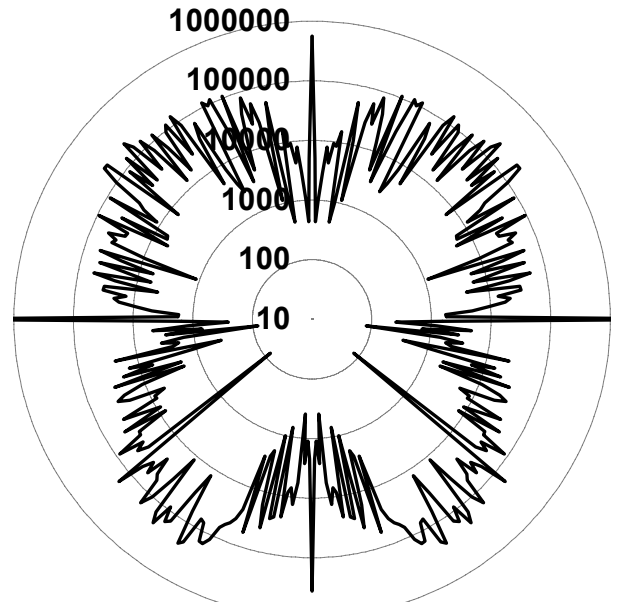

Fig. 15. The RCS circle diagram of ship model (frequency $12,6 \mathrm{GHz}$ and rough sea, vertical polarization) Source: developed by the authors.

In Fig. 16 diagrams of mean and median RCS of the ship model in three sectors of azimuth aspect are shown. In Fig. 17 diagrams of mean and median RCS of the ship model in 15-degree sectors of azimuth aspect are shown.

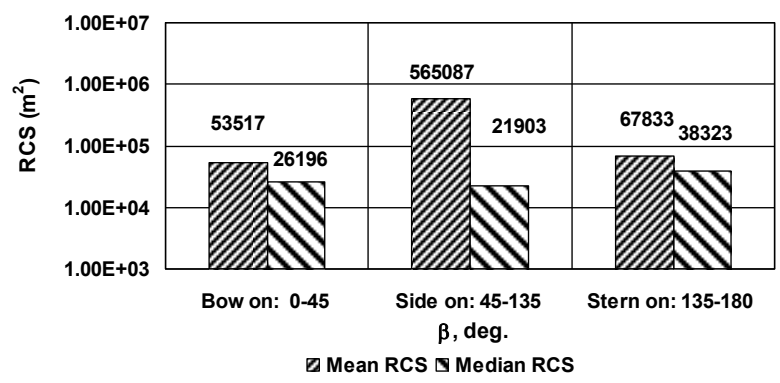

Fig. 16. Diagrams of mean and median RCS of the ship model in three sectors of azimuth aspect (frequency

$12,6 \mathrm{GHz}$ and rough sea, vertical polarization) Source: developed by the authors.

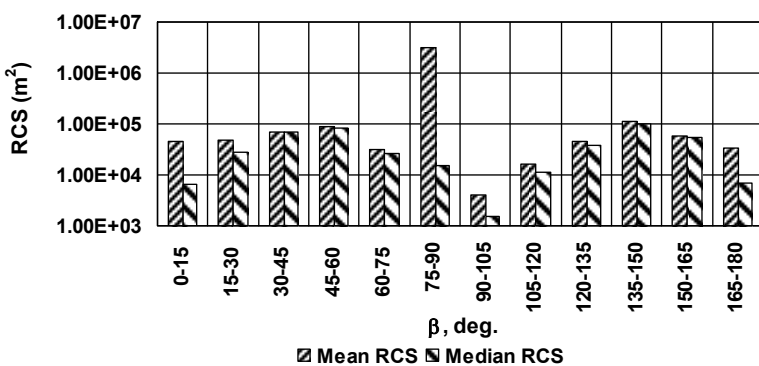

Fig. 17. Diagrams of mean and median RCS of the ship model in 15-degree sectors of azimuth aspect (frequency 12,6 GHz and rough sea, vertical polarization)

Source: developed by the authors.

Ship scattering characteristics for frequency $36,6 \mathrm{GHz}$ and smooth sea.

Horizontal polarization. In Fig. 18. the RCS circle diagram is shown. Circular mean RCS of ship model is equal $921117400 \mathrm{~m}^{2}$. Circular median RCS (RCS value used for calculation of object detection range with probability 0,5 ) is equal $26179212 \mathrm{~m}^{2}$.

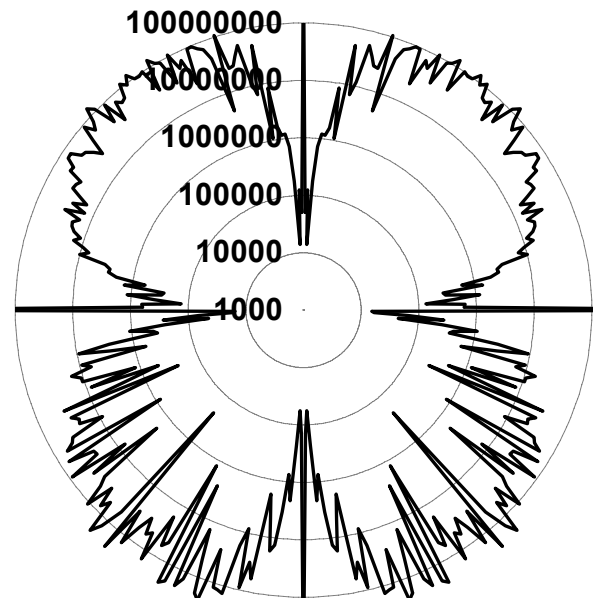

Fig. 18. The RCS circle diagram of ship model (frequency $36,6 \mathrm{GHz}$ and smooth sea, horizontal polarization)

Source: developed by the authors.

In Fig. 19 diagrams of mean and median RCS of the ship model in three sectors of azimuth aspect are shown. In Fig. 20 diagrams of mean and median RCS of the ship model in 15-degree sectors of azimuth aspect are shown.

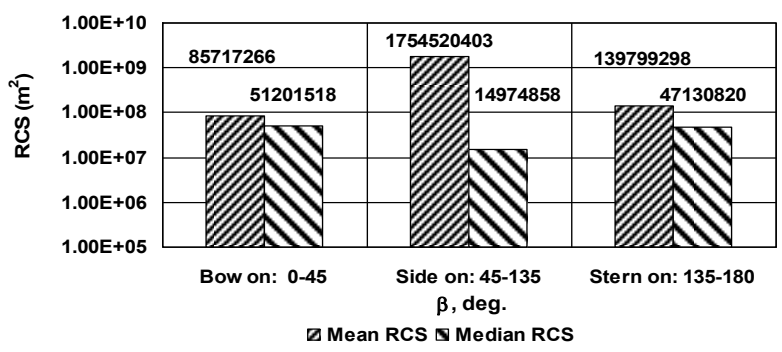

Fig. 19. Diagrams of mean and median RCS of the ship model in three sectors of azimuth aspect (frequency $36,6 \mathrm{GHz}$ and smooth sea, horizontal polarization) Source: developed by the authors. 


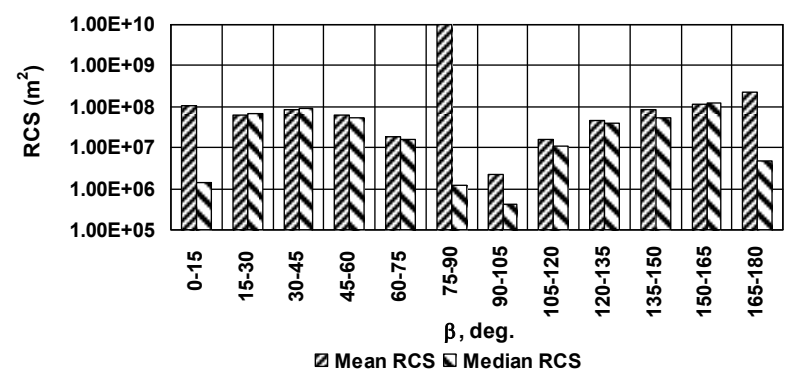

Fig. 20. Diagrams of mean and median RCS of the ship model in 15-degree sectors of azimuth aspect (frequency $36,6 \mathrm{GHz}$ and smooth sea, horizontal polarization)

Source: developed by the authors.

Vertical polarization. In Fig. 21 the RCS circle diagram is shown. Circular mean RCS of ship model is equal $876773447 \mathrm{~m}^{2}$. Circular median RCS (RCS value used for calculation of object detection range with probability 0,5 ) is equal $26159320 \mathrm{~m}^{2}$.

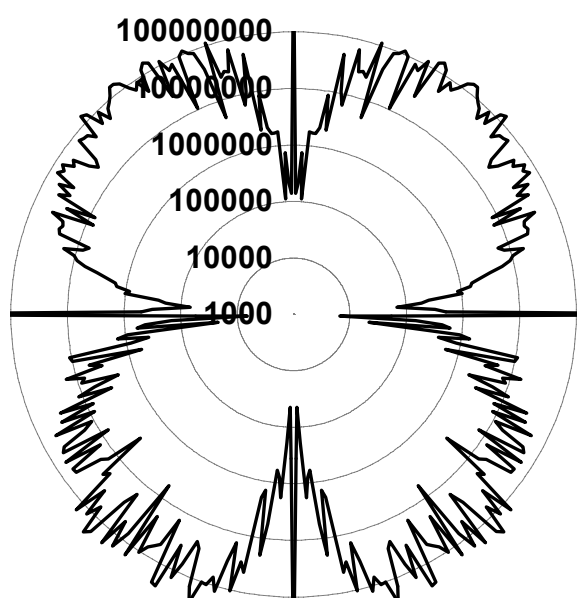

Fig. 21. The RCS circle diagram of ship model (frequency $36,6 \mathrm{GHz}$ and smooth sea, vertical polarization)

Source: developed by the authors.

In Fig. 22 diagrams of mean and median RCS of the ship model in three sectors of azimuth aspect are shown. In Fig. 23 diagrams of mean and median RCS of the ship model in 15-degree sectors of azimuth aspect are shown.

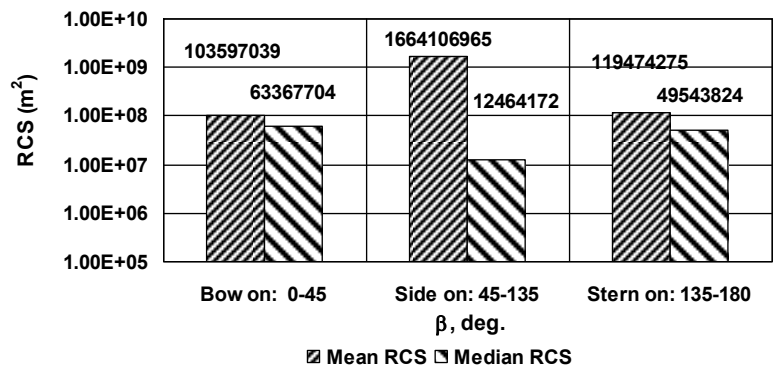

Fig. 22. Diagrams of mean and median RCS of the ship model in three sectors of azimuth aspect (frequency

$36,6 \mathrm{GHz}$ and smooth sea, vertical polarization) Source: developed by the authors.

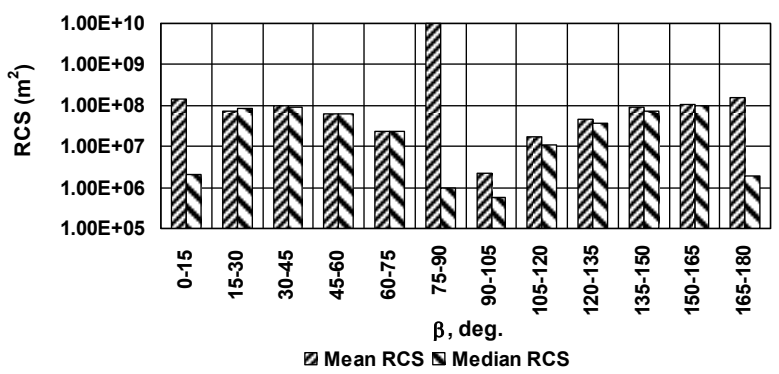

Fig. 23. Diagrams of mean and median RCS of the ship model in 15-degree sectors of azimuth aspect (frequency $36,6 \mathrm{GHz}$ and smooth sea, vertical polarization) Source: developed by the authors.

Ship scattering characteristics for frequency $36.6 \mathrm{GHz}$ and rough sea

Horizontal polarization. In Fig. 24 the RCS circle diagram is shown. Circular mean RCS of ship model is equal $5170441 \mathrm{~m}^{2}$. Circular median RCS (RCS value used for calculation of object detection range with probability 0,5 ) is equal $270086 \mathrm{~m}^{2}$.

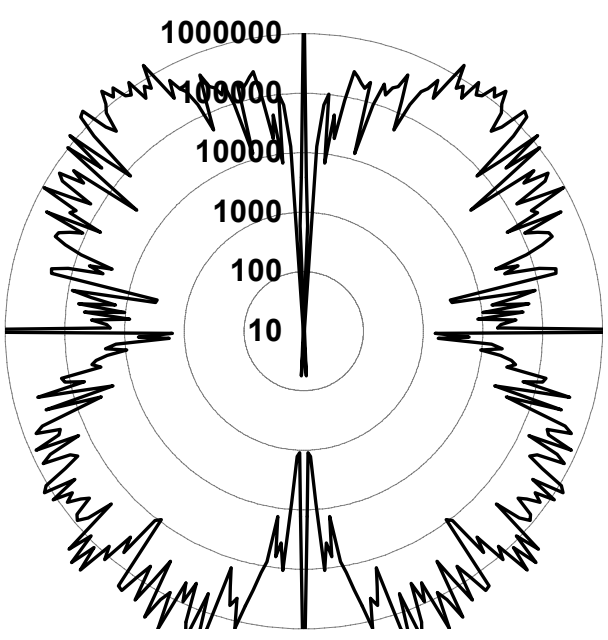

Fig. 24. The RCS circle diagram of ship model (frequency $36,6 \mathrm{GHz}$ and rough sea, horizontal polarization)

Source: developed by the authors.

In Fig. 25 diagrams of mean and median RCS of the ship model in three sectors of azimuth aspect are shown. In Fig. 26 diagrams of mean and median RCS of the ship model in 15-degree sectors of azimuth aspect are shown.

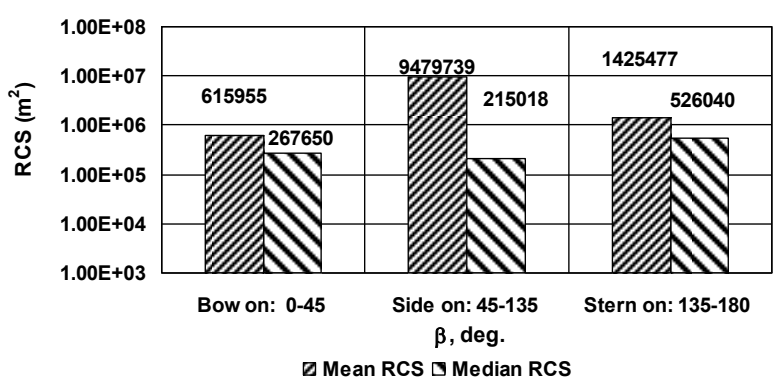

Fig. 25. Diagrams of mean and median RCS of the ship model in three sectors of azimuth aspect (frequency $36,6 \mathrm{GHz}$ and rough sea, horizontal polarization) Source: developed by the authors. 


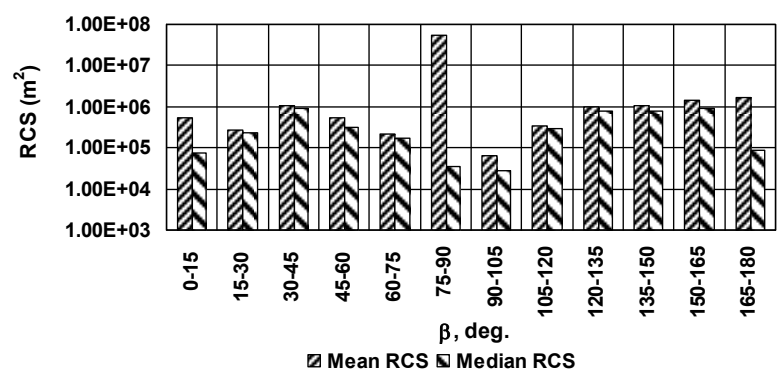

Fig. 26. Diagrams of mean and median RCS of the ship model in 15-degree sectors of azimuth aspect (frequency $36,6 \mathrm{GHz}$ and rough sea, horizontal polarization)

Source: developed by the authors.

Vertical polarization. In Fig. 27 the RCS circle diagram is shown. Circular mean RCS of ship model is equal $5055311 \mathrm{~m}^{2}$. Circular median RCS (RCS value used for calculation of object detection range with probability 0,5 ) is equal $249933 \mathrm{~m}^{2}$.

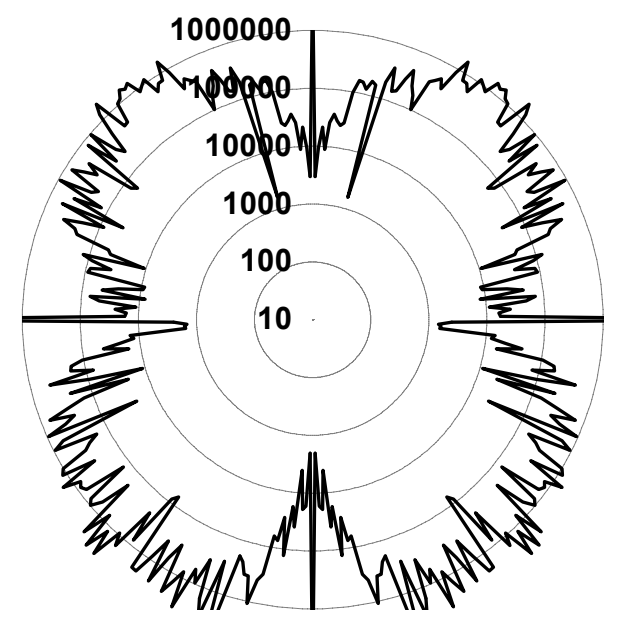

Fig. 27. The RCS circle diagram of ship model (frequency $36,6 \mathrm{GHz}$ and rough sea, vertical polarization)

Source: developed by the authors.

In Fig. 28 diagrams of mean and median RCS of the ship model in three sectors of azimuth aspect are shown. In Fig. 29 diagrams of mean and median RCS of the ship model in 15-degree sectors of azimuth aspect are shown.

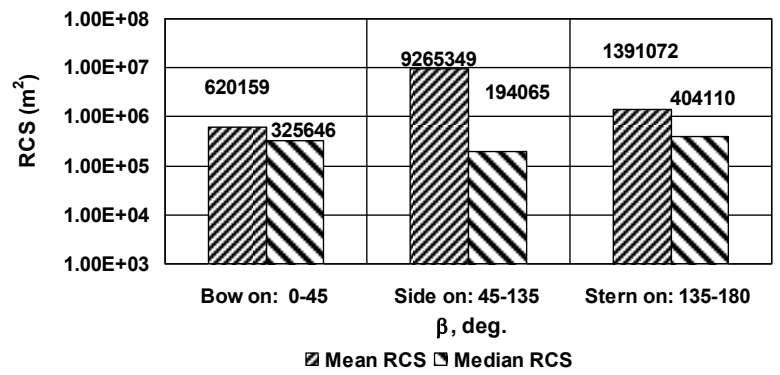

Fig. 28. Diagrams of mean and median RCS of the ship model in three sectors of azimuth aspect (frequency

$36,6 \mathrm{GHz}$ and rough sea, vertical polarization)

Source: developed by the authors.

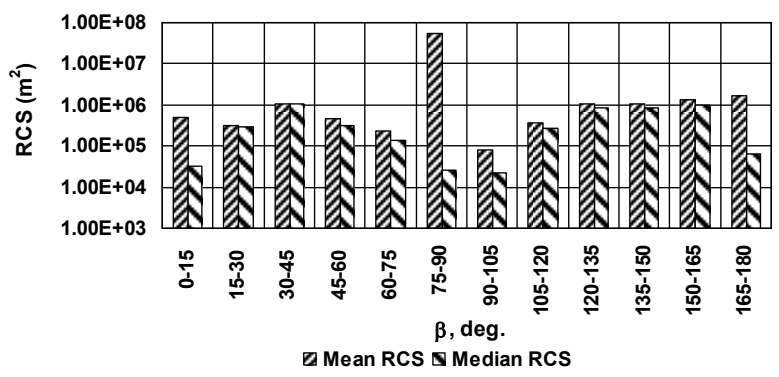

Fig. 29. Diagrams of mean and median RCS of the ship model in 15-degree sectors of azimuth aspect (frequency $36,6 \mathrm{GHz}$ and rough sea, vertical polarization)

Source: developed by the authors.

Changes in the scattering characteristics of the ship during the missile moves are of certain interest. As an example, we consider how the RCS of a LLS changes as the missile moves along one of the possible attack trajectories.

Consider the trajectory depicted in Fig. 30 in the altitude-target slant range coordinate. The bold points are the places on trajectory from that directions the ship RCS was estimated.

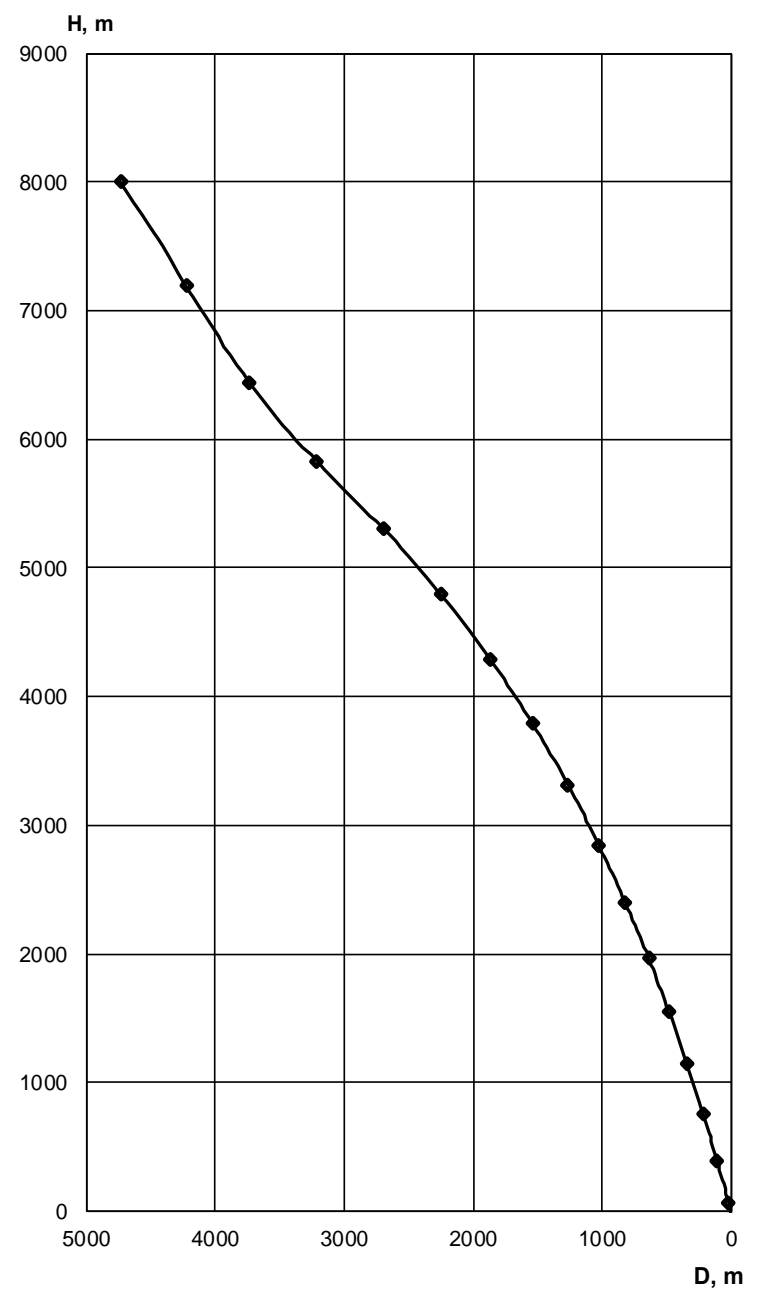

Fig. 30. Considered trajectory Source: developed by the authors. 
Let's consider the dependences of the EPR on the slant distance "missile-ship" for two azimuths of approach of the missile to the ship: $0^{\circ}, 45^{\circ}\left(0^{\circ}\right.$ corresponds to bow azimuth aspect angle, $180^{\circ}$ corresponds to stern azimuth aspect angle). The probing frequency is $36,6 \mathrm{GHz}$ - wavelength $0,81 \mathrm{~cm}$.

We present the computation results obtained in assumption of two types of sea surface. These two types are the following: smooth sea $\left(\varepsilon^{\prime}=80+j 3,4\right)$; rough sea with the same parameters but it have such roughness, that averaged reflection factor for sea surface tends to zero.

It is necessary to note that regardless of the fact that we estimate RCS in trajectory points actually we estimate RCS (as characteristic for far zone of researched object) from the direction which connects the ship (the coordinate origin) and point in missile trajectory.

For considered horizontal polarization the electric field vector of incident plane wave is parallel to sea surface.

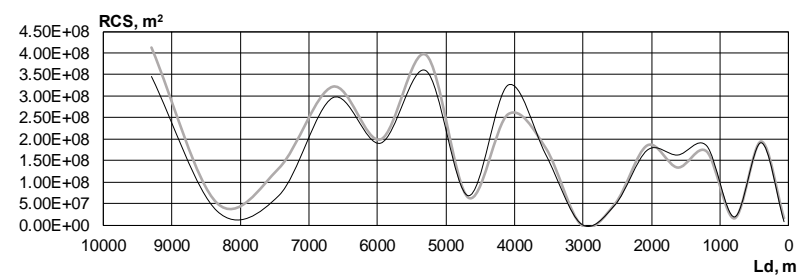

Fig. 31. The instantaneous RCS versus slant distance "missile-ship" for azimuth 0 degrees Source: developed by the authors.
Fig. 31 shows the dependence of the ship's EPR on the slant distance to it for azimuth 0 degrees, and Fig. 32 - for azimuth 45 degrees. The gray line corresponds to the dependencies for a smooth sea. The black line shows the dependencies for a rough sea.

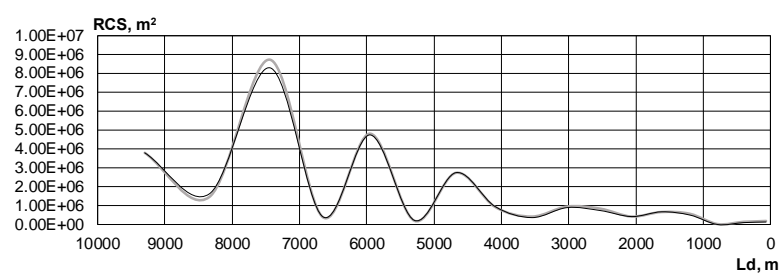

Fig. 32. The instantaneous RCS versus slant distance "missile-ship" for azimuth 45 degrees Source: developed by the authors.

Dependencies have an oscillatory character, and for azimuth 45 degrees it is strongly attenuated.

\section{Conclusion}

The paper proposes the calculation method for scattering characteristics of complex-shaped surface objects for various probing parameters. As an example, the calculation results for some scattering characteristics (circular RCS diagrams, the dependence of the RCS of an object on probing angles when the missile moves along one of the possible attack trajectories) for the project 775 LLS (NATO codification - Ropucha) are given.

\section{References}

1. Sukharevsky, O., Zalevsky, G. and Vasilets, V. (2016), Modeling of Ultra wideband (UWB) Impulse Scattering by Aerial and Subsurface Resonant Objects Based on Integral Equation Solving, Advanced Ultra wideband Radar: Signals, Targets, and Applications, J. D. Taylor ed., Boca Raton, London, New York, pp. 195-235. https://doi.org/10.1201/9781315374130.

2. Klimov, V.E. and Klishin, V.V. (1983), Axiomatization of the three dimensional object geometry synthesis problem, $I z$ vestiya Academii Nauk, USSR, Technical Cybernetics, No. 4, P. 57-62.

3. Semenov, A. (1968), Electromagnetic wave theory, MSU, Moscow.

4. Sukharevsky, O.I. (2014), Electromagnetic Wave Scattering by Aerial and Ground Radar Objects, CRC Press, 332 p.

5. Knott, E., Shaeffer, J. and Tuley, M.(1993), Radar Cross Section, $2^{\text {nd }}$ ed. Artech House, Boston, London, 611 p.

6. Shirman, Ya.D. (2007), "Radyoylektronnye systemy: Osnovy postroenyja y teoryja. Spravochnyk" [Radioelectronic Systems: Fundamentals of Construction and Theory. Directory], Radio engineering, Moscow, $512 \mathrm{p}$.

7. Markarian, G. and Staniforth, A. (2021), Countermeasures for Aerial Drones, Artech House, Boston, London, $350 \mathrm{p}$

8. Ritchie, M., Fioranelli, F. and Griffiths, H. (2015), Micro-drone RCS analysis. Proc. IEEE Radar Conference, Johannesburg, South Africa, pp. 452-456.

9. Vyshnevskyi, S.D., Beilis, L.V. and Klymchenko, V.Y. (2017), "Potentsiini mozhlyvosti RLS RTV z vyiavlennia operatyvno-taktychnykh ta taktychnykh bezpilotnykh litalnykh aparativ" [Potential capabilitys of radiotechnical troops radars to detect operational-tactical and tactical unmanned air vehicle], Science and Technology of the Air Force of Ukraine, No. 2(27), pp. 92-98. https://doi.org/10.30748/nitps.2017.27.18.

10. Molchanov, D.V., Vasylets, V.O. and Sukharevskyi, O.I. (2016), "Modeliuvannia kharakterystyk rozsiiannia velykoho desantnoho korablia" [Modeling scattering characteristics of the large Landing Ship], Scientific Works of Kharkiv National Air Force University, Vol. 2(47), pp. 76-78.

11. Dudush, A.S., Tjutjunnyk, V.O., Reznichenko, O.A. and Ghoghonjanc, S.Ju. (2018), "Suchasnyj stan ta problemy protydiji malovysotnym, nyzjkoshvydkisnym ta malorozmirnym BPLA" [Current state and problems of counteraction to lowaltitude, low-speed and small-sized UAVs], Modern information technologies in the field of security and defense, No. 1, pp. 121-131. https://doi.org/10.33099/2311-7249/2018-31-1-121-131.

12. Laučys, A., Rudys, S. and Kinka, M. (2019), Low-altitude UAV air ground propagation channel measurement and analysis in a suburban environment at $3.9 \mathrm{GHz}$, Aviation, No. 23(2), pp. 48-53. https://doi.org/10.1049/iet-map.2019.0067.

13. Gong, J., Yan, J. and Li, D. (2019), Interference of radar detection of drones by birds, Progress in electromagnetics research, No. 81, pp. 1-11. https://doi.org/10.1109/TAES.2018.2856338.

14. Riabukha, V. (2020), Radar surveillance of unmanned aerial vehicles (review). Radioelectronics communication system. No. 63(11). pp. 561-573. https://doi.org/10.3103/S0735272720110011. 
15. Kamaltynov, G. and Kolesnik, O. (2020), “Tendenciji rozvytku radiolokacijnykh zasobiv kontrolju povitrjanogho prostoru" [Tendencies for the development of radiation aircraft controls], Scientific Works of Kharkiv National Air Force University, No. 2(64), pp. 89-95. https://doi.org/10.30748/zhups.2020.64.13.

16. Gibson, W. (2008), The Method of Moments in Electromagnetics, Chapman \& Hall, Taylor \& Francis Group, Boca Raton, London, New York, 288 p.

17. Volakis, J. and Sertel, K. (2012), Integral Equation Methods for Electromagnetics, SciTech Publishing, Inc., Raleigh, NC, USA, $391 \mathrm{p}$.

\section{Список літератури}

1. Sukharevsky O., Zalevsky G., Vasilets V. Modeling of Ultra wideband (UWB) Impulse Scattering by Aerial and Subsurface Resonant Objects Based on Integral Equation Solving. Advanced Ultra wideband Radar: Signals, Targets, and Applications / J. D. Taylor ed. Boca Raton London New York, 2016. P. 195-235. https://doi.org/10.1201/9781315374130.

2. Klimov V. E., Klishin V. V. Axiomatization of the three dimensional object geometry synthesis problem. Izvestiya Academii Nauk, USSR, Technical Cybernetics. 1983. No. 4. P. 57-62.

3. Semenov A. Electromagnetic wave theory. Moscow : MSU, 1968. $332 \mathrm{p}$

4. Electromagnetic Wave Scattering by Aerial and Ground Radar Objects / Sukharevsky O. I. et al.. CRC Press, 2014.

5. Knott E., Shaeffer J., Tuley M. Radar Cross Section. $2^{\text {nd }}$ ed. Boston, London : Artech House, 1993. 611 p.

6. Радиоэлектронные системы: Основы построения и теория. Справочник / под ред. Я. Д. Ширмана. Москва : Радиотехника, 2007. $512 \mathrm{c}$.

7. Markarian G., Staniforth A. Countermeasures for Aerial Drones. Boston, London : Artech House, 2021. 350 p.

8. Ritchie M., Fioranelli F., Griffiths H. Micro-drone RCS analysis. Proc. IEEE Radar Conference. Johannesburg, South Africa, 2015. P. 452-456.

9. Вишневський С. Д., Бейліс Л. В., Климченко В. Й. Потенційні можливості РЛС РТВ з виявлення оперативнотактичних та тактичних безпілотних літальних апаратів. Наука і техніка Повітряних Сил Збройних Сил Украӥни. 2017. № 2(27). C. 92-98. https://doi.org/10.30748/nitps.2017.27.18.

10. Молчанов Д.В., Василець В.О., Сухаревський О.І. Моделювання характеристик розсіяння великого десантного корабля. Збірник наукових пращь Харківського національного університету Повітряних Сил. 2016. № 2(47). С. $76-78$.

11. Дудуш А. С., Тютюнник В. О., Резніченко О. А., Гогонянц С. Ю. Сучасний стан та проблеми протидії маловисотним, низькошвидкісним та малорозмірним БПЛА. Сучасні інформаційні технологї̈ у сфері безпеки та оборони. 2018. № 1. C. 121-131. https://doi.org/10.33099/2311-7249/2018-31-1-121-131.

12. Laučys A., Rudys S. and Kinka M. (2019), Low-altitude UAV air ground propagation channel measurement and analysis in a suburban environment at 3.9 GHz. Aviation. No. 23(2). P. 48-53. https://doi.org/10.1049/iet-map.2019.0067.

13. Gong J., Yan J., Li D. Interference of radar detection of drones by birds. Progress in electromagnetics research. 2019. No. 81. P. 1-11. https://doi.org/10.1109/TAES.2018.2856338.

14. Riabukha V. Radar surveillance of unmanned aerial vehicles (review). Radioelectronics communication system. 2020. No. 63(11). P. 561-573. https://doi.org/10.3103/S0735272720110011.

15. Камалтинов Г. Г., Колеснік О. М. Тенденції розвитку радіолокаційних засобів контролю повітряного простору. Збірник наукових праць Харківського національного університету Повітряних Сил. 2020. № 2(64). С. 89-95. https://doi.org/10.30748/zhups.2020.64.13.

16. Gibson W. The Method of Moments in Electromagnetics. Boca Raton, London, New York : Chapman \& Hall, Taylor \& Francis Group, 2008. 288 p.

17. Volakis J., Sertel K. Integral Equation Methods for Electromagnetics. Raleigh, NC, USA : SciTech Publishing, Inc., 2012, $391 \mathrm{p}$.

Received by Editorial Board 15.10.2021

Signed for Printing 14.12.2021

\section{Відомості про авторів:}

\section{Сухаревський Олег Ілліч}

доктор технічних наук професор провідний науковий співробітник

Харківського національного університету

Повітряних Сил ім. І. Кожедуба,

Харків, Україна

https://orcid.org/0000-0002-4607-5361

\section{Василець Віталій Олексійович}

доктор технічних наук старший науковий співробітник провідний науковий співробітник

Харківського національного університету

Повітряних Сил ім. І. Кожедуба

Харків, Україна

https://orcid.org/0000-0002-3614-559X

\section{Ряполов Іван Свгенович}

кандидат технічних наук

старший науковий співробітник

Харківського національного університету

Повітряних Сил ім. І. Кожедуба,

Харків, Україна

https://orcid.org/0000-0002-3139-1644

\section{Information about the authors:}

Oleg Sukharevsky

Doctor of Engineering Science Professor

Leading Researcher

of Ivan Kozhedub Kharkiv National

Air Force University,

Kharkiv, Ukraine

https://orcid.org/0000-0002-4607-5361

\section{Vitaly Vasilets}

Doctor of Engineering Science Senior Researcher

Leading Researcher

of Ivan Kozhedub Kharkiv National

Air Force University,

Kharkiv, Ukraine

https://orcid.org/0000-0002-3614-559X

\section{Ivan Ryapolov}

$\mathrm{PhD}$ in Engineering

Senior Researcher

of Ivan Kozhedub Kharkiv National

Air Force University,

Kharkiv, Ukraine

https://orcid.org/0000-0002-3139-1644 


\title{
ВТОРИННЕ ВИПРОМІНЮВАННЯ НАДВОДНИХ ОБ'ЄКТІВ СКЛАДНОЇ ФОРМИ
}

\author{
О.І. Сухаревський, В.О. Василець, І.Є. Ряполов
}

Отримання радіолокаиійної інформації про радіолокачійні об'єкти за допомогою проведення натурних та фізичних експериментів пов'язане зі значними матеріальними, організачійними та часовими витратами. Тому як найбільи доступний спосіб отримання інформаиї̈ про характеристики розсіювання можна розглядати метод математичного моделювання. Запропонований метод заснований на окремому оцінюванні вкладів гладкої та кромкової частин поверхні об'єкта у загальне розсіяне поле. При цьому повне поле на гладких ділянках поверхні об'єкта обчислюється за допомогою методу Кірхгофа або його узагальнення у разі радіопоглинаючих покриттів. Поле, розсіяне кромочними ділянками поверхні, розраховується з використанням рішення модельної задачі про дифракцію плоскої монохроматичної хвилі, щзо похило падає на ідеально провідний клин з радіопоглинаючим циліндром на ребрі. Метод дозволяє розраховувати ефективну поверхню розсіювання (ЕПР) надводного об'єкта, щяо ідеально проводить, у вільному просторі, повністю або частково покритого радіопоглинаючим матеріалом. При иьвому об'єкт може мати нерегулярності поверхні у вигляді зламів, також з радіопоглинаючими покриттями. ЕПР може бути отримана як при поєднаному, так $і$ при рознесеному прийомі. Слід зазначити, що запропонований спосіб дозволяє розраховувати ЕПР об'єкта повністю виконаного з діелектричних чи композитних матеріалів. Для надводних об'єктів пропонується метод розрахунку, що дозволяє враховувати наявність підстилаючої поверхні із заданими електромагнітними характеристиками. Через наявність межі розділу "повітря-море" на поверхні об'скта виникають дві освітлені області, щяо взасмно-перетинаються, перша з яких викликана прямою хвилею падаючої з точки опромінення, а друга - хвилею, відображеною від морської поверхні. Отримані інтегральні уявлення дозволяють вказати на чотири головні шляхи поширення електромагнітних хвиль в системі, щзо описується: "передавач-об'єкт-приймач", "передавач-об'єкт-море-приймач", "передавач-море-об'єкт-приймач", "передавач-море-об'єкт-море-приймач". Для надводних об'єктів метод також дозволяє розраховувати характеристики розсіювання за наявності поглинаючих радіопокриттів на поверхні об'єкта. На основі розробленого авторами методу оиінки вторинного випромінювання об'єктів, щзо знаходяться поблизу межі розділу двох напівпросторів, отримано характеристики розсіювання великого десантного корабля проекту 775 (за кодифікацією НАTO - Rорисһа). Наводиться модель поверхні досліджуваного корабля та результати розрахунку його вторинного випромінювання. Характеристики розсіювання отримані для різних умов опромінення. Наведено кругові діаграми ЕПР, значення середньої та медіанноі ЕПР, усереднені у різних діапазонах азимутів зондування досліджуваного об'єкта.

Ключові слова: вторинне випромінювання об'єкта, ефективна поверхня розсіювання, кругова діаграма, надводний корабель, характеристики розсіювання.

\section{ВТОРИЧНОЕ ИЗЛУЧЕНИЕ НАДВОДНЫХ ОБЪЕКТОВ СЛОЖНОЙ ФОРМЫ}

О.И. Сухаревский, В.А. Василец, И.Е. Ряполов

На основе разработанного ранее авторами метода оченки вторичного излучения объектов, находящиися вблизи границы раздела двух полупространств получены характеристики рассеяния большого десантного корабля проекта 775 (по кодификачии НАТО - Rорисhа, польск. жаба). Приводится модель поверхности исследуемого корабля и результаты расчета его вторичного излучения. Характеристики рассеяния получены для различных условий облучения. Приведены круговые диаграммы эффективной поверхности рассеяния, значения средней и медианной эффективной поверхности рассеяния, усредненные в различных диапазонах азимутов зондирования исследуемого объекта.

Ключевые слова: вторичное излучение объекта, надводный корабль, характеристики рассеяния, круговая диаграмма. 